\title{
The Influence of Transformational Leadership on Employee Performance Through Work Climate and Organizational Commitment
}

\author{
Salustiano Dos Reis Piedade \\ Graduate School Master of Business Administration (MBA), Dili Institute of Technology (DIT), Dili, Timor-Leste \\ Email: piedade0709@gmail.com
}

\begin{abstract}
The purpose of this paper is to examine the influence of transformational leadership on employee performance with work climate and organizational commitment as mediating variables. The research is conducted in the Ministry of Education of Timor-Leste. The population of this study was 765 employees in the Ministry of Education. The hypothesis testing is conducted using Smart-PLS 3.0. The results showed that transformational leadership had no effect on employee performance. The results showed that the work climate and organizational commitment play a full role in mediating the effect of transformational leadership on employee performance. This research is based on the inconsistency result of the previous studies on the effect of transformational leadership on employee performance. The inconsistency of the results of previous studies is a gap in this study. This research will integrate the work climate and organizational commitment as a mediating role in the influence of transformational leadership on employee performance.
\end{abstract}

Keywords: Transformational leadership, work climate, organizational commitment and employee performance.

\section{Introduction}

Employee performance today has become a serious concern for researchers because employee performance plays an important role in determining the success of organizational goals (Kharis, 2015; Thao and Hwang 2015; (Mangkunegara and Miftahuddin, 2016); Yusuf et al., 2014). Employee performance is one of the key factors in an organization's success in winning competition, achieving goals, and getting profits ( Zafar et al., 2017; Ayu Putu Widani Sugianingrat et al., 2019; Piedade et al., 2019). It also plays an important role in determining the success of organizational goals both profit and non-profit (Abu-jarad et al., 2010). It was involves output quality and quantity, attendance at work, accommodative nature and output timeliness (Shahzadi et al., 2014; Sihombing et al., 2018). It is indicated that the effectiveness of employee's can contributes to achieve the organizational goals (Iqbal et al., 2015).

Factors that influence employee performance are transformational leadership. Therefore, transformational leadership can motivate, guide and directing subordinates (Bass 1996:1; Avolio and Bass, 2002) to improve individual performance and ultimately improve organizational performance (García-Morales et al., 2008). Employee performance also influences by several factors, such as working hour, training, communication barriers, stress and financial reward (Iqbal et al., 2015) individual abilities, efforts spent and organizational support (Mathis and Jackson, 2011), motivation, commitment, expertise and thinking abilities (Sembiring, 2014:83-84).

Several previous studies indicate that transformational leadership had a positive and significant influence on employee performance (Tucunan et al., 2014; Andreani et al. 2016;
Pawirosumarto et al., 2017, Musa et al., 2018; Naeen and Khanzada, 2018; Manzoor et al., 2019) since a transformational leader provides spirit, motivation and energy (Griffin and Moorhead, 2010) and improves staffs' abilities, potential, ethics and trust (Naeem and Khanzada 2018). Nevertheless, there are also empirical studies that indicate that transformational leadership had no significant influence on employee performance (Koh, Steers and Terborg, 1995; Brown and Arendt, 2011; Tambalean, 2014; Jiang et al., 2017; Kertiriasih et al, 2018).

The inconsistency of these results leaves a research gap for further exploration to improve employee performance. In the current research, work climate and organizational commitment could play an important role in improving employee performance. A leader develops a good work climate by knowing and establishing good working relationship with employees (Galer et al., 2005), simplifying, having strong relationship with commitment and monitoring employee in facing challenges could improve employee performance (Ariñez et al., 2002; Suliman and Harethi 2013) (Yoon et al., 2001; Suliman and Harethi, 2013; Pawirosumarto et al., 2016; Rahsel, 2016; Abdullah Mohamed and Gaballah, 2018). Organizational commitment has influence on performance (Rubel et al., 2017). Likewise, work motivation could improve employee performance (Pritchard and Ashwood 2008; Danish et al., 2014; Skripak et al., 2016; Kinicki and Fugate; 2016).

Nevertheless, relationship between transformational leadership, work climate and organizational commitment needs to be empirically examined. It is important to fill the existing empirical gap as well as help leaders in organizations to improve employee performance through work climate and organizational commitment. Hence, the research is important to be conducted to test the influence of transformational leadership on employee 
performance and work climate and organizational commitment as a mediating role.

\section{Theoretical Framework and Hypothesis Development}

Transformational leadership is that a leader changes and inspires subordinates to work beyond expectation and interest for the good of the organization (Avolio et al., 2009). Transformational leadership provides trust and arouse employees' admiration, loyalty, respect, motivation and creativity to perform their work beyond the target (Avolio and Bass, 2002; Yulk, 2010; Vessey et al., 2014; Carmeli, et al., 2014) and improve efficiency (Mackenzi et al., 2001) that has implications on employee performance improvement (Buil et al., 2018). A transformational leader has influence on team work climate (Makaske, 2015; Imran, 2011), develops a healthy work climate (Pourbarkhordari et al., 2016), creates a flexible organizational climate and is focus so that it influences an innovative work behavior (Imran, 2011).

\subsection{Transformational Leadership and Employee Performance}

Transformational leadership at work place is important for employee performance (Elgelal and Noermijati, (2014). Leaders' roles are important to improve employee performance in directing and managing the employees to achieve organizational goals (Andreani and Petrik, 2016). Transformational leadership could motivate and inspire employees to perform their jobs. A transformational leader could become a good connector between superiors and subordinates; therefore, it creates a cooperative and transformational atmosphere that gives benefit to improve a sustainable performance (Jiang et al., 2017). Transformational leadership could influence employee performance directly as well as indirectly through motivation and work satisfaction. It means that improving employee performance will be effective if leaders could develop new ideas to facilitate work completion for employees (Elgelal and Noermijati, 2014). Some empirical studies indicate that there is a positive and significant influence between transformational leadership and employee performance (Risambessy et al., 2012; Tucunan et al., 2014;Andreani and Petrik, 2016; Pawirosumarto et al., 2017; Jiang et al., (2017; Musa et al., 2018; Khanzada et al., 2018). According to the above description, a hypothesis could be formulated as follows. Hypothesis 1: Transformational leadership has a positive and significant influence on employee performance.

\subsection{Transformational Leadership, Work Climate and Employee Performance}

The most important thing to be done by a leader is to create a positive work climate by knowing their employees and establishing good work relationship with them (Galer et al., 2005). Leaders must understand that set aside time and efforts to manage work climate is important since it will result in planned and expected work performance (Suliman and Harethi, 2013b). The reason is that positive work climate will improve extra effort by employees beyond the expectation (Ariñes $\mathrm{et}$ al., 2002; (Abdullah and Gaballah, 2018). Conducive and productive work climate and kinship are important to strengthen and maintain a bond between organization and employees and it reflects positive work result. Positive work climate allows employees to be more creative, productive and cooperative so that it could prevent obstacles in employee performance to achieve the expected goals (Galer et al., 2005:52). Work climate and positive encouragement could motivate employees to improve performance (Suliman and Harethi, 2013b), stimulate staff motivation to pursue their personal goals and in the end, they could fight to achieve the organizational goals (Bennis and Schein 1966). Work environment that provides safety and employees to work optimally could affect employee emotion. If the employees could enjoy their work environment, they will enjoy their time at work, use their working hour effectively and optimally; thus, it has implications for their performance improvement. Empirical studies indicate that work climate had a significant influence on and direct contribution to efforts and work performance (Yoon et al., 2001; Suliman and Harethi, 2013; Pawirosumarto et al., 2016; Rahsel, 2016). According to the above description, a hypothesis could be formulated as follows:

Hypothesis 2: Transformational leadership has a positive and significant influence on work climate

Hypothesis 3: Work climate has a positive and significant influence on employee performance

Hypothesis 4: Work climate could mediate the influence of transformational leadership on employee performance

\subsection{Transformational Leadership, Commitment Organizational and Employee Performance}

Transformational leadership has a strong positive relationship with employee commitment since it gives optimism and builds win-win solution between employees and organization (Danish et al., 2014). Transformational leadership style could increase employee commitment to organization; thus, employees work beyond targets set by organization (Amin et al., 2018). A transformational leader promotes values related to achievement and relationship between employee efforts and goal achievement and creates bigger personal commitment level to work to achieve organizational vision, mission and goals (Shamir et al., 1998; Batool, 2013).

Organizational commitment is an important factor to understand organizational behavior and a predictor of good employees to stay at their work (Bahrami et al., 2016). It is an emotional bond feeling of employees to their organization and work. In an organization, emotional bond is a form of loyalty that involves individual feeling to share the same values with other group members (Chowdhury, 2014). Employee commitment is crucial so as organization needs to keep the best employees and maintain employee commitment to achieve organizational goals (Sattigeri, 2016).

Commitment as a psychological mechanism connects organizational efforts to apply planned changes and employee behavior (Jaros, 2010). It is also a strong standard for turnover behavior, tendency to resign and organizational behavior 
(Sinclair et al., 2005). It reflects one's level to recognize and bond to organizational goals so that it encourages them to stay loyal and keep working hard to achieve the goals (Kreitner and Kinicki, 2014). Previous studies indicate that transformational leadership has a positive and significant effect on employee commitment (Danish et al., 2014; Han et al., 2016; Allen, Attoh and Gong, 2017; Jiang et al., 2017; Dlamini, Garg and Muchie, 2017; Waris et al., 2018; Amin et al., 2018). The research results also suggest that employee commitment had a positive impact on employee performance (Chen and Francesco, 2003; Dost and Tariq, 2012; Atmojo, 2012; Hafiz, 2017) since a committed employee will be loyal, work hard and has strong desire to achieve organizational goals (Herold et al., 2008). According to the above description, a hypothesis could be formulated as follows.

Hypothesis 5: Transformational leadership has a positive and significant influence on organizational commitment

Hypothesis 6: Organizational commitment has a positive and significant influence on employee performance

Hypothesis 7: Organizational commitment could mediate the influence of transformational leadership on employee performance.

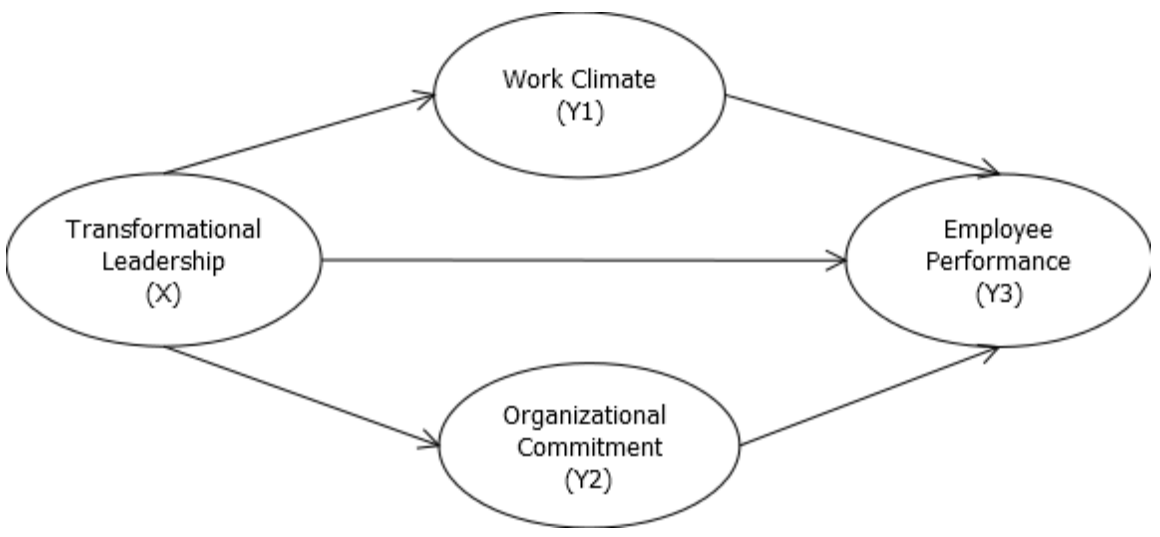

Figure 1. Conceptual Framework

\section{Research Method}

\subsection{Population and Sample}

The research population target was civil servants in the national as well as district levels of the Ministry of Education of Timor-Leste. In collecting the necessary data from statistics using stratify random sampling. Based on the geographical area, it is divided into 4 regions and autonomous regions (region I, Region II, Region III, Region IV, and RAEOA-Oecuse). In addition, the sample is determined based on the position; top management, middle management, and lower level management. After preparing a list of employees based on region and position, 263 respondents were selected from 765 employees using the Slovin's formula with an accuracy level of 5\%. From 263 respondents were selected through simple random sampling. After that, 263 questionnaires were distributed and all were filled out properly and could be used for analysis (Gray et al., 2007:110; Creswell 2013:220; Cowles and Nelson 2015:22). The number of sample was statistically usable since according to Wolf et al., (2013) the minimum sample is between 30 to 460 respondents if using Smart-Partial Least Square (SmartPLS 3.0) analysis. It is supported by Hair et al. (2014) stated that the minimum sample for Smart-PLS is 30. The data were processed using, Microsoft excel, and analyzed using SMART-PLS 3.0.

\subsection{Data Analysis Techniques}

Data collected were analyzed using Smart-PLS 3.0 (Ringle et al., 2015) that has several advantages, namely: it does not require classic assumption tests and it can be used for small size sample, reflective and formative indicators (Hair et al., 2014; Aguirre-urreta 2015; Henseler et al. 2016). PLS is an established technique to calculate path coefficient. It could predict construct, analyzes multi-variance data, develops and tests relationship between variables based on theories and is a method that riches in management and strategy researches (Hair et al., 2014; Valaei and Jiroudi, 2016). The outer model (reliability and validity) test and hypothesis testing used PLS with parameters from Hair et al. (2014), and (Henseler, Ringle and Sarstedt, 2015).

\subsection{Measurement}

In this research, transformational leadership was measured using four dimensions consisted of 12 indicators (Ashikali and Groeneveld, 2015). Work climate was measured using indicators developed by Management Sciences for Health (MSH's) (Galer et al., 2005). Work motivation was measured by indicators adapted from Chang and Chen (2008) cited by (Shahzadi et al., 2014), and employee performance was measured by indicators adapted from (Koopmans, 2014). Whereas, the mediation role testing was conducted to determine indirect influence between the variables, transformational leadership, work climate, organizational commitment and 
employee performance. The test is basically conducted to find out whether or not the mediating variables fully mediate, partially mediate or do not mediate the variables (Baron and Kenny, 1986) cited by Sholihin and Ratmono (2013). Memon et al., 2018 stated that Baron and Kenny's approach is widely recognized and it is still a good reference and one the most read papers to understand the mediation theory.

\section{Result Analysis}

\subsection{Outer Model Evaluation}

Reliability test used parameters of outer loadings, Composite Reliability (CR), and Average Variance Extracted (AVE) (Hair et al., 2014).

The test results indicated that all outer loading indicators were above 0.6 (Table III) (hair 2006) cited by (Wardana et al., 2019), the minimum Composite Reliability (CR) value was
0.757 and the Average Variance Extracted (AVE) minimum value was 0.5 (Table I). The results suggested that all constructs had good internal consistency to be used in analyzing relationship between variables where the $\mathrm{CR}$ value was greater than 0.70 (Hair et al., 2014).

The construct validity test used Discriminant Validity with Fornell Larscker Criterion (Hair et al., 2014), heterotraitmonotrait $\left(\mathrm{HTMT}_{90}\right)$ by Henseler et al., 2015, and cross loadings (Hair et al., 2011; Hair et al., 2014)). The result of discriminant validity test with Fornell-Larcker Criterion values (Table II) indicated that all latent variables had good discriminant validity. Heterorotrait-manotrait HTMT $_{90}$ (Table III) showed that the highest value was 0.9 and cross loadings (Table IV) suggested that each indicator from one variable was greater than other cross loadings. Therefore, all construct were valid to be used as they met the requirements (Hair et al., 2011; Hair et al., 2014; Henseler et al., 2015).

Table 1. Construct Validity

\begin{tabular}{|c|c|c|c|}
\hline Notation & Variable & Composite reliability & Average Variance Extracted (AVE) \\
\hline $\mathbf{X}$ & Transformational Leadership & 0.896 & 0.619 \\
\hline Y1 & Work Climate & 0.757 & 0.509 \\
\hline Y2 & Organizational Commitment & 0.863 & 0.591 \\
\hline Y3 & Employee Performance & 0.861 & 0.511 \\
\hline
\end{tabular}

Table 2. Discriminant Validity - Fornell-Larcker Criterion

\begin{tabular}{|c|c|c|c|c|c|c|c|c|c|c|c|c|c|}
\hline Model & X & $\mathrm{X} 1$ & $\mathrm{X} 2$ & X3 & X4 & Y1 & Y2 & Y2.1 & $\mathrm{Y} 2.2$ & Y2.3 & Y3 & Y3.1 & Y3.2 \\
\hline $\mathbf{X}$ & 0.650 & & & & & & & & & & & & \\
\hline X1 & 0.791 & 0.775 & & & & & & & & & & & \\
\hline $\mathrm{X} 2$ & 0.822 & 0.589 & 0.784 & & & & & & & & & & \\
\hline X3 & 0.833 & 0.493 & 0.552 & 0.816 & & & & & & & & & \\
\hline X4 & 0.858 & 0.562 & 0.585 & 0.678 & 0.772 & & & & & & & & \\
\hline Y1 & 0.227 & 0.173 & 0.276 & 0.087 & 0.219 & 0.713 & & & & & & & \\
\hline Y2 & 0.526 & 0.486 & 0.342 & 0.454 & 0.448 & 0.263 & 0.625 & & & & & & \\
\hline Y2.1 & 0.402 & 0.319 & 0.286 & 0.341 & 0.374 & 0.367 & 0.709 & 0.758 & & & & & \\
\hline Y2.2 & 0.453 & 0.436 & 0.276 & 0.385 & 0.394 & 0.178 & 0.894 & 0.474 & 0.764 & & & & \\
\hline Y2.3 & 0.417 & 0.409 & 0.273 & 0.377 & 0.318 & 0.127 & 0.798 & 0.350 & 0.585 & 0.783 & & & \\
\hline Y3 & 0.257 & 0.204 & 0.301 & 0.136 & 0.211 & 0.505 & 0.360 & 0.386 & 0.220 & 0.308 & 0.640 & & \\
\hline Y3.1 & 0.234 & 0.204 & 0.287 & 0.097 & 0.190 & 0.440 & 0.299 & 0.280 & 0.185 & 0.287 & 0.909 & 0.699 & \\
\hline Y3.2 & 0.225 & 0.157 & 0.248 & 0.148 & 0.186 & 0.467 & 0.347 & 0.419 & 0.208 & 0.262 & 0.883 & 0.607 & 0.731 \\
\hline
\end{tabular}


Table 3. Cross Loadings

\begin{tabular}{|c|c|c|c|c|c|c|c|c|c|c|}
\hline $\begin{array}{l}\text { Dimension/ } \\
\text { Indicator }\end{array}$ & X1 & $\mathrm{X} 2$ & X3 & 4 & 1 & 22.1 & Y2.2 & 2.3 & 3.1 & Y3.2 \\
\hline X11 & 4 & 1 & 392 & 32 & 87 & 28 & 18 & 147 & 26 & 06 \\
\hline $\mathbf{X}$ & & 79 & 80 & 90 & 43 & 78 & 252 & 275 & 149 & 15 \\
\hline $\mathrm{X} 1$ & 187 & 487 & .376 & 484 & .170 & .240 & .254 & 238 & 0.196 & .144 \\
\hline $\mathrm{X} 21$ & 414 & .757 & .377 & .358 & 193 & .138 & .071 & .086 & 159 & .107 \\
\hline X22 & 444 & 816 & 0.435 & 23 & 37 & 00 & 52 & 57 & 01 & .275 \\
\hline $\mathrm{X} 23$ & 2 & 9 & 1 & 31 & 88 & & 04 & & & 19 \\
\hline X31 & 59 & 0.499 & 0 & & & & & & 771 & 10 \\
\hline $\mathbf{X}$ & 56 & 0.429 & 0.810 & & 0.146 & 246 & 289 & 0.243 & 062 & 0.162 \\
\hline X3 & & 0.419 & 0.822 & 0.545 & 0.034 & 301 & 317 & 0.329 & 103 & 0.099 \\
\hline $\mathrm{X}$ & & 0.329 & 0.326 & 0.610 & 0.219 & .346 & 308 & 146 & 226 & 0.274 \\
\hline X & 495 & 0.505 & 0.576 & 0.017 & 0.094 & .200 & 264 & 279 & 0.144 & 0.052 \\
\hline & 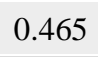 & 97 & 0.622 & 0.862 & 17 & 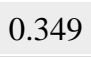 & T & 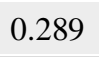 & T & .153 \\
\hline & & & & & & & & & & 年 \\
\hline Y12 & & & & & & & & & & 34 \\
\hline Y & 0.135 & 9 & 0 & 0 & 97 & 73 & 91 & 77 & 00 & 0.351 \\
\hline Y2.11 & 0.252 & 0.181 & 0.315 & 0.331 & 0.215 & 0.808 & 0.367 & 0.314 & 0.229 & 0.304 \\
\hline Y2.12 & 0.280 & 0.222 & 0.317 & 0.314 & 0.261 & 0.811 & 0.410 & 0.308 & 0.190 & 0.309 \\
\hline Y2.13 & 0.183 & 0.268 & 0.109 & 0.186 & 0.400 & 0.644 & 0.289 & 0.148 & 0.229 & 0.360 \\
\hline Y2.21 & .365 & 0.239 & 0.319 & 0.328 & .206 & 0.448 & .769 & .429 & 164 & 0.198 \\
\hline & & & 0. & & & & & & & 153 \\
\hline & & & & & & & & & & 105 \\
\hline & & & & & & & & & & 0.177 \\
\hline & & & & & & & & & & 0.199 \\
\hline & & & & & & & & & & 0.312 \\
\hline Y2.33 & 0.278 & 0.198 & & 0.274 & 0.006 & 0.182 & 0.407 & & & 0.097 \\
\hline Y3.11 & 155 & 0.185 & 0.077 & 0.147 & 0.338 & 0.189 & 0.048 & 246 & 710 & 0.449 \\
\hline Y3.12 & 159 & 0.214 & 0.046 & 0.106 & 359 & .162 & .125 & 0.164 & 696 & 0.438 \\
\hline $\mathbf{Y}$ & & & & & & & & & & .382 \\
\hline $\mathbf{Y}$ & & 0.200 & 0.012 & & & & & 35 & & 0.447 \\
\hline Y3.15 & 0.114 & & 0 & 0 & 53 & & 46 & 36 & & 0.400 \\
\hline & & & & & & & 0.215 & 0.201 & 0.500 & 0.775 \\
\hline Y3.22 & 0.064 & & 0.022 & 0.070 & 0.357 & 0.253 & 0.075 & 0.128 & 0.505 & 0.783 \\
\hline Y3.23 & & & 0.288 & 0.261 & 0.264 & & 0.295 & 0.330 & 0.331 & 0.658 \\
\hline Y3.24 & 0.089 & 0.176 & 0.049 & 0.077 & 0.376 & 0.271 & 0.045 & 0.137 & 0.137 & -7 \\
\hline
\end{tabular}


Table 4. Discriminant Validity - HTMT

\begin{tabular}{|c|c|c|c|c|c|c|c|c|c|c|c|c|c|}
\hline $\begin{array}{l}\text { Dimension/ } \\
\text { Indicators }\end{array}$ & $X$ & $\mathrm{X} 1$ & $\mathrm{X} 2$ & $\mathrm{X} 3$ & $\mathrm{X} 4$ & Y1 & Y2 & Y2.1 & Y 2.2 & Y2.3 & Y3 & Y3.1 & Y3.2 \\
\hline \multicolumn{14}{|l|}{$\mathbf{X}$} \\
\hline $\mathrm{X} 1$ & 0.845 & & & & & & & & & & & & \\
\hline $\mathrm{X} 2$ & 0.829 & 0.864 & & & & & & & & & & & \\
\hline X3 & 0.815 & 0.695 & 0.761 & & & & & & & & & & \\
\hline $\mathrm{X} 4$ & 0.812 & 0.841 & 0.850 & 0.901 & & & & & & & & & \\
\hline Y1 & 0.352 & 0.293 & 0.461 & 0.169 & 0.393 & & & & & & & & \\
\hline Y2 & 0.622 & 0.658 & 0.452 & 0.575 & 0.619 & 0.459 & & & & & & & \\
\hline Y2.1 & 0.538 & 0.488 & 0.441 & 0.473 & 0.593 & 0.675 & 0.807 & & & & & & \\
\hline Y2.2 & 0.555 & 0.613 & 0.372 & 0.506 & 0.567 & 0.310 & 0.802 & 0.675 & & & & & \\
\hline Y2.3 & 0.537 & 0.609 & 0.386 & 0.530 & 0.461 & 0.275 & 0.797 & 0.511 & 0.802 & & & & \\
\hline Y3 & 0.322 & 0.288 & 0.400 & 0.185 & 0.326 & 0.775 & 0.455 & 0.550 & 0.285 & 0.412 & & & \\
\hline Y3.1 & 0.299 & 0.290 & 0.398 & 0.132 & 0.302 & 0.712 & 0.389 & 0.418 & 0.246 & 0.398 & 0.896 & & \\
\hline Y3.2 & 0.314 & 0.255 & 0.360 & 0.230 & 0.321 & 0.767 & 0.486 & 0.652 & 0.302 & 0.385 & 0.817 & 0.829 & \\
\hline
\end{tabular}

Table 5. R-Square

\begin{tabular}{|l|c|c|}
\hline \multicolumn{1}{|c}{ Variable } & R Square & R Square Adjusted \\
\hline Work Climate (Y1) & 0.052 & 0.048 \\
\hline Organizational Commitment (Y2) & 0.277 & 0.274 \\
\hline Employee performance (Y3) & 0.311 & 0.304 \\
\hline
\end{tabular}

Inner model evaluation generally uses such parameters as coefficient of determinant $\left(\mathrm{R}^{2}\right)$, Inner model predictive relevance $\left(\mathrm{Q}^{2}\right)$, goodness of fit $(\mathrm{GoF})$, and Effect size $\left(\mathrm{f}^{2}\right)$ (Hair et al., 2014). The result of coefficient of determinant $\left(\mathrm{R}^{2}\right)$ test can be seen in Table 5. $\mathrm{Q}^{2}$ could be determined based on the $\mathrm{R}^{2}$ value. The $\mathrm{Q}^{2}$ calculation resulted in a value of 0.527 ; thus, the model was a strong model as a whole (Razak, Rahman and Borhan, 2016). Goodness of fit (GoF) calculation obtained a value of 0.345 ; hence, the model was very fit as a whole (Tenenhaus, 2004) cited by Wardana et al., 2018; Kumar and Banerjee, 2014).

\subsection{Hypothesis Testing}

The result of hypothesis testing is illustrated in Figure 2 and the value of path coefficients and probabilities are presented in Table 6 . The testing results suggested that path coefficient estimation value of indirect influence of transformational leadership on employee performance was 0.041 with t-statistics of $0.675<0.196$ and probability value (p-value) of 0.500 , which was insignificant in confidence level of $95 \%$. The testing results could not prove the occurred realities so that Hypothesis $1\left(\mathrm{H}_{1}\right)$ stating that transformational leadership has a significant influence on employee performance was rejected. However, based on the positive sign of the path coefficient the relationship between transformational leadership and employee performance was linear. The results indicated that the better the transformational leadership the higher the employee performance, although the linear relationship was insignificant.

The result of estimation value test of the influence of transformational leadership on work climate was 0.227 with $\mathrm{t}$ statistics of $3.667>1.96$ and probability value (p-value) of 0.000 , which was significant at the confidence level of $95 \%$. The results brought enough evidence to accept hypothesis $2\left(\mathrm{H}_{2}\right)$ stating that the better the transformational leadership the better the work climate. The linear relationship suggested that transformational leadership was capable of improving work climate.

The result of estimation value test of the influence of work climate on employee performance was 0.437 with t-statistics of $8.036>1.96$ and probability value ( $\mathrm{p}$-value) of 0.000 , which was significant at the confidence level of $95 \%$. The results suggested sufficient proof to accept hypothesis $3\left(\mathrm{H}_{3}\right)$ stating that the better the work climate the higher the employee performance. The 
linear relationship indicated that work climate was able to improve employee performance.

The result of estimation value test of the influence of transformational leadership on organizational commitment was 0.526 with t-statistics of $10.770>1.96$ and probability value ( $\mathrm{p}$ value) of 0.000 , which was significant at the confidence level of 955. It means there was sufficient proof to accept Hypothesis 4 $\left(\mathrm{H}_{4}\right)$ stating that the better the transformational leadership the higher the organizational commitment. The linear relationship suggested that transformational leadership was capable of improving organizational commitment.

The result of estimation value test of the influence of organizational commitment on employee performance was 0.224 with t-statistics of $3.947>1.96$ and probability value (pvalue) of 0.000 , which was significant at the confidence level of $95 \%$. It means there was sufficient proof to accept Hypothesis $5\left(\mathrm{H}_{5}\right)$ stating that the better the organizational commitment the higher the employee performance. The linear relationship suggested that organizational commitment was able to improve employee performance.

The result of path coefficient evaluation on the direct influence of transformational leadership on employee performance (c) obtained a value of 0.325 with t-statistics of $5.288>1.96$ and probability value of 0.000 , which was significant at the confidence level of $95 \%$ in the first step. The path coefficient test of indirect influence of transformational leadership on work climate (a) was 0.227 with t-statistics of
$3.667>1.96$ and probability value of 0.000 . The path coefficient value of the influence of work climate on employee performance (b) was 0.437 with t-statistics of 8.036>1.96 and probability value of 0.000 indicating that both variables were significant. The path coefficient value of the influence of transformational leadership on employee performance (c") was smaller (decreased) of 0.041 with t-statistics of $0.675<1.96$ and probability value of 0.500 and became insignificant in the second stage. The results suggested that $a$ and $b$ values were significant but c" was insignificant; therefore, work climate variable in the research model was a perfect mediating variable (full mediation). Thus, the hypothesis 6 was accepted.

Moreover, the coefficient of the influence of transformational leadership on organizational commitment (a) was 0.526 with t-statistics of 10.770>1.96 and probability value of 0.000 . The path coefficient value of the influence of organizational commitment on employee performance (b) was 0.224 with t-statistics of $3.947>1.96$ and probability value of 0.000 indicating that both variables were significant. The path coefficient value of the influence of transformational leadership on employee performance (c") was smaller (decreased) of 0.041 with t-statistics of $0.675<1.96$ and probability value of 0.500 and became insignificant in the second stage. The results suggested that $a$ and $b$ values were significant but c" was insignificant; therefore, organizational commitment variable in the research model was a perfect mediating variable (full mediation). Thus, the hypothesis 7 was accepted.

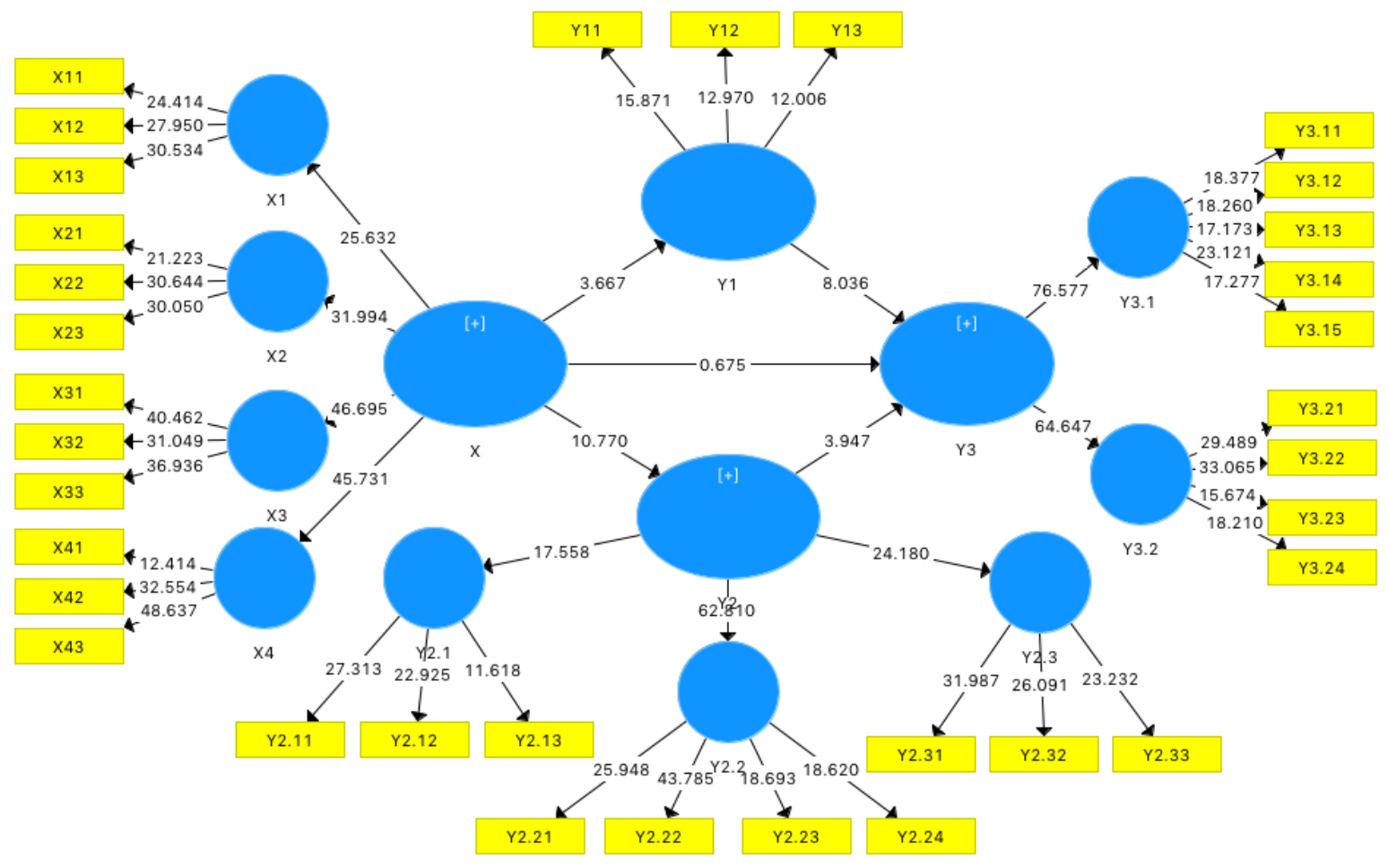

Figure 2. Path Coefficient Indirect Effect 


\section{Discussion \\ 5.1. Relationship Between Transformational Leadership and Employee Performance}

The research aimed to test the influence of transformational leadership on employee performance. The research results indicated that transformational leadership had no influence on employee performance. One factor causing the transformational leadership to have no influence on performance was related to turnover of leaders that often occurred. As a consequence, the leadership did not have sufficient time to implement transformational leadership values in improving employee performance to achieve organizational mission and vision. The research results confirmed previous research by (Koh et al., 1995) stated that transformational leadership had no influence on employee performance due to the lack of work time and intellectual stimulation. Factors causing the lack of relationship between transformational leadership and employee performance might be related to respondents who were less consistent in giving a rank, afraid of revenge possibility, bias, less commitment or no relationship (Brown and Arendt, 2011). Nevertheless, the research results indicated a positive sign in path coefficient suggesting that the relationship between transformational leadership and employee performance was linear. It implied that the better the transformational leadership the higher the employee performance despite the insignificant relationship.

The research results were symmetric to previous research results stating that transformational leadership had no positive and significant influence on performance (Koh et al., 1995; Brown and Arendt, 2011; Tambalean, 2014; Jiang et al., 2017; Kertiriasih et al, 2018; Prabowo et al., 2018; Vipraprastha et al., 2018). On the contrary, the research results contradicted several previous empirical studies indicating that transformational leadership had positive and significant influence on employee performance (Mathisen, Einarsen and Mykletun, 2012; Cavazotte, 2013; Ekaningsih, 2014; İşcan et al., 2014; Abas and Advani, 2015; Ng, 2016; Andreani and Petrik, 2016; Asrar-ulhaq and Kuchinke, 2016; Al-Amin, 2017; Naeem and Khanzada, 2018; Altunoğlu et al., 2018; Buil, Martínez and Matute, 2019).

\subsection{Relationship Between Transformational Leadership and Work Climate}

The research results indicated that transformational leadership had a positive and significant influence on work climate. The application of transformational leadership values would improve work climate since the most important thing must be done by a leader is creating positive work climate by knowing his/her employees and establishing good work relationship with them (Galer et al., 2005). In addition, it is important to manage work climate appropriately since it will result in planned and expected work performance (Suliman and Harethi, 2013). Moreover, the research results indicated that work climate had a positive and significant influence on employee performance. Good work climate would motivate employees to improve their performance optimally. In this condition, the employees would feel that they are in a situation where they fight towards their and organizational goals (Benis and Schein, 1966; Galer et al., 2005).

\subsection{Relationship Between Work Climate and Employee Performance}

The research results indicated that a hypothesis stating that work climate has a positive and significant influence on employee performance was proven. Positive work climate would provide a condition for employee to be creative and productive since a cooperative work place could prevent things that could hinder employee performance to achieve the expected goals (Galer et al., 2005; Suliman and Hareti, 2013). Good work climate will affect employee behavior (Al-Omari and Okasheh, 2017). Therefore, work climate is an important factor for organizational members' behavior so that it requires attention from leaders since it will influence employee behavior (Hasanah et al., 2010). The research results confirmed several previous researches stating that work climate had a positive and significant influence on employee performance (Pawirosumarto et al., 2016; Rahsel, 2016; Latief, 2017; Alzghoul et al., 2018. Hence, work climate is an important factor that must be considered by leaders in an organization.

\subsection{The Roles of Work Climate in Mediating the Influence of Transformational Leadership on Employee Performance}

The research results indicated that a hypothesis stating that work climate could mediate transformational leadership in employee performance was proven. Schulte et al., (2009) stated that climate plays an important role in understanding employee attitude. Conducive and productive work climate as well as kinship is important to strengthen and maintain a bond between organization and employees and it reflects productive work result (Galer et al., 2005). Therefore, work climate is a psychological process that mediates a relationship between work environment, attitude and behavior (Tesluk, Fara and Klein, 1997) that has implication for productivity improvement (Nair, 2006). For that reason, organization obliges to create good work climate to help leaders in behaving since work climate influences leaders' vision and the way they work as well as influence the way employees work to think more creative and innovative in performing their jobs to improve employee performance. Empirical studies indicate that transformational leadership had a positive influence on work climate (Arinez et al., 2002; Galer et al., 2005; Orabi, 2016). Additionally, several empirical studies also indicate that work climate had a positive and significant influence on employee performance (Yoon et al., 2001, Suliman and Harethi 2013; Latief, 2017; Alzghoul et al., 2018). Therefore, work climate plays an important role in mediating transformational leadership and employee performance to achieve organizational performance. 


\subsection{Relationship Between Transformational Leadership and Organizational Commitment}

The research results indicated that a hypothesis stating that transformational leadership has a positive and significant influence on organizational commitment was proven. It was shown by transformational leadership that had a positive and strong relationship with employee commitment (Danish et al., 2014). Shamir et al., (1998) stated that employee commitment could be improved through transformational leadership. The research results confirmed previous research stating that there was a positive and significant influence between employee commitment level and organization and transformational leadership style (Amin et al., 2018), (Fajrin, Saragih and Indratjahjo, 2018), (Gathungu, Iravo and Namusonge, 2015). By appropriately applying transformational leadership values will improve organizational commitment to achieve organizational performance.

\subsection{Relationship Between Organizational Commitment and Employee Performance}

The research result indicated that a hypothesis stating that organizational commitment has a positive and significant influence on employee performance was proven. It was due to organizational commitment that was an important factor and as a predictor that employees remain in their work (Bahrani et al., 2016). If an employee are increasingly committed then the lower their desire to leave the organization. In the context of change, Herold et al. (2008) stated that commitment is not only a positive attitude but it goes along with intention to support and a willingness to work hard to achieve success. Khan and Zia-udDin (2010) also stated that organizational commitment is closely related to employee work performance. The research results confirmed the results of previous researches stating that organizational commitment had a positive influence on employee performance (Chen and Francesco, 2003; (Atmojo, 2012); (Dost and Tariq, 2012); (Bandula and Jayatilake, 2016); (Fajrin, Saragih and Indratjahjo, 2018). Therefore, organizational commitment is an important factor in determining employee performance to achieve organizational goals.

\subsection{The Roles of Organizational Commitment in Mediating the Influence of Transformational Leadership on Employee Performance}

The research results indicated that a hypothesis stating that organizational commitment has a positive and significant influence on employee performance was proven. Boxall and Macky (2007) stated that when an employee has high commitment to organization it has implication for employee performance improvement and organizational performance as a whole (Owoyemi et al., 2011). In addition, (Chen and A. Francesco, 2003) stated that employees who have high effective commitment they will do their job more than what assigned to them. Empirical studies suggested that transformational leadership had an influence on employee performance. Likewise, organizational commitment had an influence on employee performance. The research results indicated that the relationship between transformational leadership, organizational commitment and employee performance was in line to theoretical studies. The results suggested that organizational commitment played a role in the relationship between transformational leadership and employee performance.

\section{Conclusions and Implication}

The research results indicated that transformational leadership had no significant influence on employee performance. It was due to leader's turnover that often occurred. As a consequence, leadership did not have sufficient time to implement transformational leadership values in improving employee performance to achieve organizational mission and vision. The research results confirmed previous researches by (Koh et al., 1995; Brown and Arendt, 2011; Tambalean, 2014; Jiang et al., 2017; Kertiriasih et al, 2018). Work climate and organizational commitment played a full role in mediating the influence of transformational leadership on employee performance. The reason was that by applying transformational leadership values it could improve and raise work climate and organizational commitment that leads to employee performance improvement (Bass, 1995; Geijsel et al., 2003; Amin et al., 2018). Therefore, transformational leadership had an indirect and significant influence on employee performance through mediating roles. The research results indicated that the relationship between transformational leadership, organizational commitment and employee performance was in line with the theoretical studies.

The research contributes to leadership theory, especially transformational leadership as well as organizational behavior that is related to the mediating role of work climate and organizational commitment in improving employee performance. This, in turn, could lead to the achievement of organizational goals. In practical level, the research could contribute to organization managers to create organizational climate and encourage commitment to improve employee performance as a condition to improve organizational performance.

\section{Limitations and Further Research}

The research had been conducted maximally; however, due to the wide scope of discussion, the research has several limitations. The research was built on an integrated model but the research finding showed that the model accuracy was only 0.527. It means that the variance of transformational leadership, work climate, organizational commitment and employee performance variables by the model was $52.7 \%$ and the remaining was explained by other variables. The result can not be genelarized due the sample size only 263 respondent. Therefore, for the next reserach to consider to increase the sample size. Therefore, it is expected that further researchers 
could add other variables that could improve employee performance.

\section{References}

Abas, Z. and Advani, A. (2015) 'Impact of Transformational and Transactional Leadership Styles on Employees' Performance of Banking Sector in Pakistan', Global Journal of Management and Business Research, 14(5), pp. 29-36.

Abdullah Mohamed, H. and Gaballah, S. (2018) 'Study of the Relationship between Organizational Climate and Nurses' Performance: A University Hospital Case', American Journal of Nursing Research, 6(4), pp. 191-197. Doi:10.12691/ajnr-6-4-7.

Abu-jarad, I. Y., Yusof, N. and Nikbin, D. (2010) 'A Review Paper on Organizational Culture and Organizational Performance', International Journal of Business and Social Science, 1(3), pp. 2646.

Aguirre-urreta, M. I. (2015) 'Sample Size Determination and Statistical Power Analysis in PLS Using R: An Annotated Tutorial', Communications of the Association for Information Systems, 36(3), pp. 33-51. Doi:10.17705/1CAIS.03603.

Al-Amin, M. (2017) 'Transformational Leadership and Employee Performance Mediating Effect of Employee Engagement', North South Business Review, 7(2), pp. 28-40.

Allen, G. W., Attoh, P. A. and Gong, T. (2017) 'Transformational leadership and affective organizational commitment: Mediating roles of perceived social responsibility and organizational identification', Social Responsibility Journal, 13(3), pp. 585-600.

Altunoğlu, A. E., Şahin, F. and Babacan, S. (2018) 'Transformational leadership, trust, and follower outcomes: a moderated mediation model', Management Research Review, xx(xx), pp. xx-xx. Doi:10.1108/MRR-01-2018-0036.

Alzghoul, A. et al. (2018) 'Knowledge management, workplace climate, creativity and performance: The role of authentic leadership', Journal of Workplace Learning, 30(8), pp. 592-612.

Amin, W. et al. (2018) 'Impact of Transformation Leadership on Affective Employee' s Commitment', European Online Journal of Natural and Social Sciences, 7(1), pp. 48-57.

Andreani, F. and Petrik, A. (2016) 'Employee Performance as the Impact of Transformational Leadership and Job Satisfaction in PT Anugerah Baru Denpasar', Journal Manajemen and Kewirausahaan, 18(1), pp. 25-32.

Ariñez, A. et al. (eds) (2002) 'Management Strategies for Improving Health Services'

Asrar-ul-haq, M. and Kuchinke, K. P. (2016) 'Impact of leadership styles on employees ', attitude towards their leader and performance: Empirical evidence from Pakistani banks', Future Business Journal. Elsevier, 2(1), pp. 54-64. Doi:10.1016/j.fbj.2016.05.002.

Atmojo, M. (2012) 'The influence of transformational leadership on job satisfaction, organizational commitment and employee performance', International Journal of Business Studies, 5(2), pp. 113-128. Doi:10.21632/irjbs.5.2.113-128.

Avolio, B. J. and Bass, B. M. (2002) Developing potential across a full range of leadership: Cases on transactional and transformational leadership. Lawrence Erlabaum Associates, New Jersey.

Avolio, B. J., Walumbwa, F. O. and Weber, T. J. (2009) 'Leadership: Current Theories, Research, and Future Directions', Annual Review of Psychology, 60(1), pp. 421-449. Doi:10.1146/annurev.psych.60.110707.163621.

Bahrami, M. A. et al. (2016) 'Role of Organizational Climate in Organizational Commitment: The Case of Teaching Hospitals', Osong Public Health and Research Perspectives. Elsevier Korea LLC, 7(2), pp. 96-100. Available at: Doi:10.1016/j.phrp.2015.11.009.

Bandula, P. . M. K. . U. and Jayatilake, L. V. K. (2016) 'Impact of Employee Commitment on Job Performance: Based on Leasing Companies in Sri Lanka', International Journal of Arts and Commerce, 5(8), pp. 8-22.

Baron, R. M. and Kenny, D. A. (1986) 'The Moderator-Mediator Variable Distinction in Social Psychological Research. Conceptual, Strategic, and Statistical Considerations', Journal of Personality and Social Psychology, 51(6), pp. 1173-1182. Doi: 10.1037/00223514.51.6.1173.

Bass, B. M. (1995) 'Theory of Transformational Leadership Redux’, Leadership Quarterly, 6(4), pp. 463-478.

Bass, B. M. (1996) A new paradigm of Leadership. U.S. Army Research Insititure for the Behavioral \& Sosial Sciences.

Batool, B. F. (2013) 'An Empirical Study on Effect of Transformational Leadership On Organizational Commitment In The Banking Sector Of Pakistan', IOSR Journal of Business and Management, 8(2), pp. 38-44. Doi: 10.9790/487X-0823844.

Boxall, P. and Macky, K. (2007) 'High performance work systems and organisational performance: Bridging theory and practice', Asia Pacific Journal of Human Resources, 45(3), pp. 261-270.

Brown, E. A. and Arendt, S. W. (2011) 'Perceptions of transformational leadership behaviors and subordinates' performance in hotels', Journal of Human Resources in Hospitality and Tourism, 10(1), pp. 45-59. Doi:10.1080/15332845.2010.500205.

Buil, I., Martínez, E. and Matute, J. (2018a) 'Transformational leadership and employee performance: The role of identification, engagement and proactive personality', International Journal of Hospitality Management, xxx(xxxx), pp. xxx-xxx.

Buil, I., Martínez, E. and Matute, J. (2018b) 'Transformational leadership and employee performance: The role of identification, engagement and proactive personality', International Journal of Hospitality Management, $\operatorname{xxx}(\mathrm{xxx}), \quad$ p. $\mathrm{xxx}$. Doi: 10.1016/j.ijhm.2018.06.014.

Carmeli, A. et al. (2014) 'Transformational leadership and creative problem-solving: The mediating role of psychological safety and 
reflexivity', in Journal of Creative Behavior, pp. 115-135. Doi: 10.1002/jocb.43.

Cavazotte, F., Moreno, V. and Bernardo, J. (2013) 'Transformational Leaders and Work Performance : The Mediating Roles of Identification and Self-efficacy', Brazilian Administration Review, 10(4), pp. 490-512. Doi: 10.1590/S180776922013000400007.

Chen, Z. X. and Francesco, A. (2003) 'The Relationship Between the Three Components of Commitment and Employee Performance in China', Journal of Vocational Behavoir, pp. 1-16.

Chen, Z. X. and Francesco, A. M. (2003) 'The relationship between the three components of commitment and employee performance in China', Journal of Vocational Behavior, 62(3), pp. 490-510. Doi: 10.1016/S0001-8791(02)00064-7.

Chowdhury, R. G. (2014) 'A Study on the Impact of Leadership Styles on Employee Motivation and Commitment: An Empirical Study of Selected Organizationes in Corporate Sector', Disertation.

Cowles, E. L. and Nelson, E. (2015) An Introduction to Survey Research. 1st Editio. Business Expert Press, LLC.

Creswell, J. W. (2013) Research Design Qualitative, Quantitative, and Mixed Methods Approaches. 3rd Editio. Sage Publication, Inc.

Danish, R. Q. et al. (2014) 'The Impact of Transformational Leadership and Employee Commitment on Organizational Citizenship', Sci.Int.(Lahore), 26(5), pp. 2451-2455.

Dlamini, N. N. N., Garg, A. K. and Muchie, M. (2017) 'The impact of transformational leadership style on organisational commitment in the hospitality industry', African Journal of Hospitality, 6(3), pp. $1-21$.

Dost, M. . K. Bin and Tariq, S. (2012) 'Employee Commitment and Their Performance Are Inter- Related : a Behavioral Study From Pakistan', Arabian Journal of Business and Management Review, 1(7), pp. 125-139.

Ekaningsih, A. S. (2014) 'The Effect of Transformational Leadership on the Employees 'Performance through Intervening Variables of Empowerment, Trust, and Satisfaction ( A Study on Coal Companies in East Kalimantan )', European Journal of Business and Management, 6(22), pp. 111-117.

Elgela, K. S. K. and Noermijati (2014) 'The Influences of Transformational Leaderships on Employees Performance (A Study of the Economics and Business Faculty Employee at University of Muhammadiyah Malang)', Asia-Pacific Management and Business Application, 1(3), pp. 48-66. Doi: 10.21776/ub.apmba.2014.003.01.4.

Fajrin, D., Saragih, B. and Indratjahjo, H. (2018) 'The Effect of Organizational Commitment and Organizational Culture to Employee Performance through Behaviour Civilization Organizations of Teachers and Employees Madrasah Ibtidaiya Nurussyifa Indonesia', International Journal of Business and Applied Social Science (IJBASS), 4(3), pp. 51-70.

Galer, J. B., Vriesendorp, S. and Ellis, A. (2005) 'Improving work climate to strengthen performance', in Robert Stringer (ed.)
Managers Who Lead. Management Sciences for Health, pp. 51-79.

García-Morales, V. J., Lloréns-Montes, F. J. and J., V.-J. A. (2008) 'The Effects of Transformational Leadership on Organizational Performance through Knowledge and Innovation *', British Journal of Management, 19, pp. 299-319.

Gathungu, E. W. M., Iravo, M. A. and Namusonge, G. S. (2015) 'Transformational Leadership and Employee's Commitment: Empirical Review', IOSR Journal Of Humanities And Social Science, 20(7), pp. 1-7. Doi: 10.9790/0837-20720107.

Geijsel, F. et al. (2003) 'Transformational leadership effects on teachers' commitment and effort toward school reform', Journal of Educational Administration, 41(3), pp. 228-256. Doi:10.1108/09578230310474403.

Gray, P. S. et al. (2007) The research Immagination: An Introdution to Qualitative and Quantitative Methods, Cambridge University Press. Cambridge University Press.

Griffin, R. W. and Moorhead, G. (2010) Oranizational Behavior: managing People and Organizations. 10 Edition. Cengage Learning products.

Hafiz, A. (2017) 'Relationship between organizational commitment and employee's performance evidence from banking sector of Lahore', Journal of Business and Management Review, 7(2), pp. 2 7. Doi:10.4172/2223-5833.1000304.

Hair, J. F., Hult, G. T. M., et al. (2014) A primer On Partial Least Squares Structural Equation Modeling (PLS-SEM). Sage Publication, Inc.

Hair, J. F., Sarstedt, M., et al. (2014) 'Partial least squares structural equation modeling (PLS-SEM) An emerging tool in business research', European Business Review, 26(2), pp. 106-121.

Hasanah, D. S., Fattah, H. N. and Prihatin, E. (2010) 'Pengaruh pendidikan latihan (diklat) kepemimpinan guru dan iklim kerja terhadap kinerja guru sekolah dasar se kecamatan babakancikao kabupaten purwakarta', Jurnal Pendidikan Pelatihan, 11(2), pp. 90105.

Henseler, J., Hubona, G. and Ray, P. A. (2016) 'Using PLS path modeling in new technology research: updated guidelines', Industrial Management \& Data Systems, 116(1), pp. 2-20. doi:10.1108/IMDS-09-2015-0382.

Henseler, J., Ringle, C. M. and Sarstedt, M. (2015) 'A new criterion for assessing discriminant validity in variance-based structural equation modeling', open access at Springerlink.com, 43, pp. 115135. Doi:10.1007/s11747-014-0403-8.

Herold, D. M. et al. (2008) 'The effects of transformational and change leadership on employees' commitment to a change: a multilevel study.', The Journal of applied psychology, 93(2), pp. 346-57. Doi:10.1037/0021-9010.93.2.346.

Imran, R. (2011) 'Mediating Effect of Organizational Climate between Transformational Leadership and Innovative Work Behaviour', Pakistan Journal of Psychological Research, 26(2), pp. 183-199. 
Iqbal, A. et al. (2015) 'Factors affecting the employee's performance: a case study of banking sector in pakistan', European Journal of Business and Social Sciences, 4(8), pp. 309-318.

İşcan, Ö. F., Ersarı, G. and Naktiyok, A. (2014) 'Effect of Leadership Style on Perceived Organizational Performance and Innovation: The Role of Transformational Leadership Beyond the Impact of Transactional Leadership - An Application among Turkish SME's', Procedia - Social and Behavioral Sciences, 150, pp. 881-889. Doi: 10.1016/j.sbspro.2014.09.097.

Jaros, S. (2010) 'Commitment to Organizational Change: A Critical Review', Journal of Change Management, 10(1), pp. 79-108. Doi:10.1080/14697010903549457.

Jiang, W., Zhao, X. and Ni, J. (2017a) 'The impact of transformational leadership on employee sustainable performance: The mediating role of organizational citizenship behavior', $\begin{array}{llll}\text { Sustainability } \quad \text { (Switzerland), } & 9(9), \quad \text { pp. 1-17. }\end{array}$ Doi:10.3390/su9091567.

Jiang, W., Zhao, X. and Ni, J. (2017b) 'The impact of transformational leadership on employee sustainable performance: The mediating role of organizational citizenship behavior', Sustainability (Switzerland).

Kertiriasih, N. N. R., Sujana, I. W. and Suardika, I. N. (2018) 'The Effect of Leadership Style to Job Satisfaction, Employee Engagement and Employee Performance (Study at PT. Interbat, Bali, Nusra, and Ambon)', International Journal of Contemporary Research and Review, 9(3), pp. 20592-20600. Doi: 10.15520/ijcrr/2018/9/03/468

Khan, M. R. and Zia-ud-Din (2010) 'The impact of Organizational Commitment on Employees Job Performance', European Journal of Social Sciences, 15(3), pp. 292-298. Doi: 10.2139/ssrn.1570544.

Khanzada, B., Naeem, S. and Butt, H. (2018) 'Emotional Intelligence Influence on Employee's/Organizational Performance with Mediating Role of Job Satisfaction in Pakistani Health Sector', Journal of Health Education Research \& Development, 6(2), pp. 16. Doi:10.4172/2380-5439.1000253.

Kharis, I. (2015) 'Pengaruh gaya kepemimpinan transformasional terhadap kinerja karyawan dengan mptivasi kerja sebagai variabel intervening (studi pada karyawan bank jatim cabang malang), Jurnal Administrasi Bisnis, pp. 1-9.

Kinicki, A. and Fugate, M. (2016) Organizational behavior: A Practical, Problem-Solving Approach. First edit. McGraw-Hill Education.

Koh, W. L., Steers, R. M. and Terborg, J. R. (1995) 'The effects of transformational leadership on teacher attitudes and student performance in Singapore', Journal of Organizational Behavior, 16, pp. 319-333. Doi.:10.1002/job.4030160404.

Koopmans, L. (2014) Measuring Individual Work Performance. Linda Koopmans, The Netherlands. Available at: http//:www.Measuring Individual Work Performance - TNO Publications.

Kreitner, R. and Kinicki, A. (2014) Orgnizational Behavior. 9th edn. McGraw-Hill.
Kumar, G. and Banerjee, R. N. (2014) 'Supply chain collaboration index: An instrument to measure the depth of collaboration', Benchmarking: An International Journal, 21(2), pp. 184-204. Doi:10.1108/BIJ-02-2012-0008.

Latief, N. (2017) 'Relationship Work Motivation and Working Climate on Employee Performance at PT. Perkebunan Nusantara VI', International Journal of Development Research, 7(8), pp. 14341-14345.

Mackenzie, S. B., Podsakoff, P. M. and Rich, G. A. (2001) 'Transformational and Transactional Leadership and Salesperson Performance The Dangers of Poor Construct Conceptualization View project', Journal of the Academy of Marketing Science, 29(2), pp. 115-134. Doi:10.1177/03079459994506.

Makaske, I. (2015) 'The effect of leadership behavior on work climate and team effectiveness', University of Twente, The Faculty of Behavioural, Management and Social sciences.

Mangkunegara, A. A. A. P. and Miftahuddin (2016) 'The Effect of Transformational Leadership and Job Satisfaction on Employee Performance', Universal Journal of Management, 4(4), pp. 189195.

Mathis, R. L. and Jackson, J. H. (2011) Human Resource Management. 13th Editi. Joseph Sabatino-.

Mathisen, G. E., Einarsen, S. and Mykletun, R. (2012) 'Creative leaders promote creative organizations', International Journal of Manpower, 33(4), pp. 367-382. Doi:10.1108/01437721211243741.

Naeem, S. and Khanzada, B. (2018) 'Role of Transformational Leadership in Employee's Performance with Mediating Role of Job Satisfaction in Health Sector of Pakistan', Journal of Health Education Research \& Development, 6(1), pp. 1-6.

Nair, R. (2006) 'Climate studies and associated best practices to improve climate issues in the workplace', Proceedings of the 2006 WEPAN Conference.

Ng, T. W. H. (2016a) 'Transformational leadership and performance outcomes: Analyses of multiple mediation pathways', Leadership Quarterly. Elsevier B.V., $\operatorname{xxx}(\operatorname{xxx}), \quad$ p. $\quad x x x$. Doi:10.1016/j.leaqua.2016.11.008.

Ng, T. W. H. (2016b) 'Transformational leadership and performance outcomes: Analyses of multiple mediation pathways', The Leadership Quarterly. Elsevier B.V., xxx, pp. xxx-xxx.

Orabi, T. G. A. (2016) 'The Impact of Transformational Leadership Style on Organizational Performance: Evidence from Jordan', International Journal of Human Resource Studies, 6(2), pp. 89-102. Doi:10.5296/ijhrs.v6i2.9427.

Owoyemi, O. A. et al. (2011) 'Enhancing Employees' Commitment to Organisation through Training', International Journal of Business and Management, 6(7), pp. 280-286. Doi:10.5539/ijbm.v6n7p280.

Pawirosumarto, S., Sarjana, P. K. and Gunawan, R. (2016) 'The Effect of Work Environment, Leadership Style, and Organizational Culture towards Job Satisfaction and Its Implication towards 
Employee Performance in Parador Hotels and Resort, Indonesia', International Journal of Law and Management, 58(2), pp. 1-21.

Pawirosumarto, S., Sarjana, P. K. and Muchtar, M. (2017) 'Factors affecting employee performance of PT.Kiyokuni Indonesia', International Journal of Law and Management, 59(4), pp. 602-614. Doi.:10.1108/IJLMA-03-2016-0031.

Piedade, S. D. R. et al. (2019) 'The role of motivation: the effect of transformational leadership on employee performance', International research journal of management, IT and social sciences, 6(6), pp. 253-263. Doi:10.21744/irjmis.v6n6.803.

Pourbarkhordari, A., Zhou, E. H. (Iris) and Pourkarim, J. (2016) 'Role of Transformational Leadership in Creating a Healthy Work Environment in Business Setting', 8(3), pp. 57-70.

Prabowo, T. S., Noermijati and Irawanto, D. W. (2018) 'Leadership and Work Motivation on Employee Performance Mediated by Job Satisfaction', Journal of Applied Management (JAM), 16(1), pp. 171-178. Doi:10.21776/ub.jam.2018.016. 01.20.

Pritchard, R. and Ashwood, E. (2008) Managing motivation : a manager's guide to diagnosing and improving motivation. Routledge Taylor \& Francis Group.

Rahsel, Y. (2016) 'Pengaruh Iklim Kerja Terhadap Kinerja pegawai Administrasi Pusat Universitas Padjadjaran Namdung ( Studi Pada Bagian Administrasi Umum UNPAD )', 02(01), pp. 105-117..

Razak, N. A., Rahman, Z. A. and Borhan, H. (2016) 'Modeling firm resources -enterprise risk management relationships: An empirical finding using PLS-SEM', World Journal of Entrepreneurship, Management and Sustainable Development, 12(1), pp. 35-49. Doi:10.1108/WJEMSD-05-2015-0026.

Rubel, M. R. B., Rimi, N. N. and Walters, T. (2017) 'Roles of Emerging HRM and Employee Commitment: Evidence from the Banking Industry of Bangladesh', Global Business Review, 18(4), pp. 876-894. Doi:10.1177/0972150917692223.

Sattigeri, R. C. (2016) 'Employee Retention and Commitment', International Journal of Engineering Technology, Management and Applied Sciences, 4(4), pp. 77-81.

Schein, E. H. and Bennis, W. G. (1965) Personal and Organizational Change Through Group Methods: The Laboratory Approach. John Wiley \& Sons, Inc. Doi:10.1177/074171366701700211.

Schulte, M. et al. (2009) 'Organizational climate configurations: relationships to collective attitudes, customer satisfaction, and financial performance.', The Journal of applied psychology, 94(3), pp. 618-634. Doi:10.1037/a0014365.

Shahzadi, I. et al. (2014) 'Impact of Employee Motivation on Employee Performance', European Journal of Business and ManagementOnline), 6(23), pp. 2222-2839.

Shamir, B. et al. (1998) 'Correlates of charismatic leader behavior in military units: Subordinates' attitudes, unit', Academy of management journal, 41(4), pp. 387-409.

Sihombing, S. et al. (2018) 'The effect of servant leadership to rewards, organizational culture, and its implication to employee's performance', 60(2), pp. 168-181.

Sinclair, R. R. et al. (2005) 'Performance differences among four organizational commitment profiles.', The Journal of applied psychology, 90(6), pp. 1280-1287. Doi:10.1037/00219010.90.6.1280.

Skripak, S. J., Cortes, A. and Walz, A. (2016) 'Motivating Employees', in Fundamentals of Business. Pamplin College of Business and Virginia Tech Libraries, pp. 231-241.

Sugianingrat, I. A. P. W. et al. (2019) 'The employee engagement and OCB as mediating on employee performance', International Journal of Productivity and Performance Management, 68(2), pp. 319-339. Doi:10.1108/IJPPM-03-2018-0124.

Suliman, A. and Harethi, B. Al (2013a) 'Perceived work climate and employee performance in public security organizations in the UAE', Transforming Government: People, Process and Policy, 7(3), pp. 410-424. doi:10.1108/TG-03-2012-0001.

Suliman, A. and Harethi, B. Al (2013b) 'Perceived work climate and employee performance in public security organizations in the UAE', Transforming Government: People, Process and Policy, 7(3), pp. 410-424.

Tambalean, F. P. (2014) 'The Effect of Work Stress and Leadership Styles on Employee Performance Pt. BNI (Persero) Tbk. Manado Branch', 2(4), pp. 301-308. Doi:10.35794/emba.v2i4.6265.

Tesluk, P. E., Fara, J. L. and Klein, S. R. (1997) 'Influences of Organizational Culture and Climate on Individual Creativitv', Journal of Creative Behavior, 31(1), pp. 27-41.

Thao, T. L. T. and Hwang, C. J. (2015) 'Factors affecting employee performance - Evidence from Petrovietnam Engineering Consultancy J.S.C', Journal of Management Research.

Tucunan, R. J. A., Supartha, W. G. and Riana, I. G. (2014) 'Pengaruh Kepemimpinan Transformasional Terhadap Motivasi dan Kinerja Karyawan (Sudi Kasus Pada PT. Pandawa)', E-Jurnal Ekonomi dan Bisnis Universitas Udayana, 9(3), pp. 533-550.

Valaei, N. and Jiroudi, S. (2016) 'Job Satisfaction and Job Performance in the Media Industry: A Synergistic Application of Partial Least Squares Path Modelling', Asia Pacific International Journal of Marketing, 28(5), pp. 984-1014. Doi:10.1108/APJML10-2015-0160.

Vessey, W. B. et al. (2014) 'Leadership of highly creative people in highly creative fields: A historiometric study of scientific leaders', Leadership Quarterly. Elsevier Inc., 25(4), pp. 672-691. Doi:10.1016/j.leaqua.2014.03.001

Vipraprastha, T., Sudja, I. N. and Yuesti, A. (2018) 'The Effect of Transformational Leadership and Organizational Commitment to Employee Performance with Citizenship Organization (OCB) Behavior as Intervening Variables (At PT Sarana Arga Gemeh Amerta in Denpasar City)', International Journal of Contemporary Research and Review, 9(02), pp. 20503-20518. Doi:10.15520/ijcrr/2018/9/02/435.

Wardana, I. M. et al. (2019) 'Cultural Tourism and Ecotourism 
Empowerment in the Sustainable Tourism Development and Destination Competitiveness Enhancement', Journal of Environmental Management and Tourism, 10(4), pp. 753-762. Doi:10.14505/jemt.v10.4(36).06.

Wolf, E. J. et al. (2013) 'Sample size requirements for Structural Equation Models: An evaluation of power, bias, and solution propriety', Educational and Psychological Measurement, XX(X), pp. 1-22. Doi:10.1177/0013164413495237.

Yoon, M. H., Beatty, S. E. and Suh, J. (2001) 'The effect of work climate on critical employee and customer outcomes: An employeelevel analysis', International Journal of Service Industry Management, 12(5), pp. 500-521. Doi:10.1108/EUM0000000006095.

Yulk, G. (2010) Leadership in organizations. 7 Edtion. Prentice Hall.

Yusuf, M. O., Muhammed, U. D. and Kazeem, A. O. (2014) 'Management of Leadership Style: An Approach to Organizational Performance and Effectiveness in Nigeria', International Journal of Humanities Social Sciences and Education, 1(2), pp. 17-29. 